\title{
TGF- $\beta$ and Opioid Receptor Signaling Crosstalk Results in Improvement of Endogenous and Exogenous Opioid Analgesia under Pathological Pain Conditions
}

\author{
Aquilino Lantero, ${ }^{1,2}$ Mónica Tramullas, ${ }^{1,2}$ Fuencisla Pílar-Cuellar, ${ }^{1,3,4}$ Elsa Valdizán, ${ }^{1,3,4}$ Rosa Santillán,,${ }^{1,5}$ \\ Bernard P. Roques, ${ }^{6,7}$ and María A. Hurlé ${ }^{1,2}$ \\ ${ }^{1}$ Departamento de Fisiología y Farmacología, Facultad de Medicina, Universidad de Cantabria, 39011 Santander, Spain, ${ }^{2}$ Instituto de Formación e \\ Investigación Marqués de Valdecilla, 39011 Santander, Spain, ${ }^{3}$ Instituto de Biomedicina y Biotecnología de Cantabria IBBTEC, 39011 Santander, Spain, \\ ${ }^{4}$ Centro de Investigación Biomédica en Red de Salud Mental, Instituto de Salud Carlos III, Spain, ${ }^{5}$ Departamento de Anestesiología y Reanimación, Hospital \\ Universitario Valdecilla, Santander, Spain, ${ }^{6}$ Pharmaleads SAS, 75013 Paris, France, and 7Université Paris-Descartes, 75006 Paris, France
}

\begin{abstract}
Transforming growth factor- $\beta 1$ (TGF- $\beta 1$ ) protects against neuroinflammatory events underlying neuropathic pain. TGF- $\beta$ signaling enhancement is a phenotypic characteristic of mice lacking the TGF- $\beta$ pseudoreceptor BAMBI (BMP and activin membrane-bound inhibitor), which leads to an increased synaptic release of opioid peptides and to a naloxone-reversible hypoalgesic/antiallodynic phenotype. Herein, we investigated the following: (1) the effects of BAMBI deficiency on opioid receptor expression, functional efficacy, and analgesic responses to endogenous and exogenous opioids; and (2) the involvement of the opioid system in the antiallodynic effect of TGF- $\beta 1$. BAMBI-KO mice were subjected to neuropathic pain by sciatic nerve crash injury (SNI). Gene (PCR) and protein (Western blot) expressions of $\mu$ - and $\delta$-opioid receptors were determined in the spinal cord. The inhibitory effects of agonists on the adenylyl cyclase pathway were investigated. Two weeks after SNI, wild-type mice developed mechanical allodynia and the functionality of $\mu$-opioid receptors was reduced. By this time, $B A M B I-\mathrm{KO}$ mice were protected against allodynia and exhibited increased expression and function of opioid receptors. Four weeks after SNI, when mice of both genotypes had developed neuropathic pain, the analgesic responses induced by morphine and RB101 (an inhibitor of enkephalin-degrading enzymes, which increases the synaptic levels of enkephalins) were enhanced in BAMBI-KO mice. Similar results were obtained in the formalin-induced chemical-inflammatory pain model. Subcutaneous TGF- $\beta 1$ infusion prevented pain development after SNI. The antiallodynic effect of TGF- $\beta 1$ was naloxone-sensitive. In conclusion, modulation of the endogenous opioid system by TGF- $\beta$ signaling improves the analgesic effectiveness of exogenous and endogenous opioids under pathological pain conditions.
\end{abstract}

Key words: BAMBI; inflammatory pain; morphine; neuropathic pain; RB101; TGF- $\beta$

\section{Introduction}

Physiological pain alerts the body to the presence of tissue damage or disease. The painful experience is proportional to the intensity of the stimulus, triggers defensive responses that aim to protect the organism, and disappears once the injury is overcome. However, after neural damage or inflammation or sometimes in the absence of any identifiable cause, pain may persist long after the injury has healed because of the establishment of

Received 0ct. 15, 2013; revised March 12, 2014; accepted March 13, 2014

Author contributions: M.T., R.S., and M.A.H. designed research; A.L., F.P.-C., and E.V. performed research; B.P.R. contributed unpublished reagents/analytic tools; A.L., M.T., F.P.-C., E.V., R.S., and M.A.H. analyzed data; A.L., M.T., and M.A.H. wrote the paper.

This work was supported by Ministerio de Ciencia e Innovación Grant SAF2010-16894, Fundació La Marató de TV3 Grant 072131, Instituto de Salud Carlos III Grant RTICS:RD06/001/1016, and Sociedad Española de Farmacología and Laboratorios Almirall-Prodesfarma.

The authors declare no competing financial interests.

Correspondence should be addressed to Dr. María A. Hurlé, Department of Physiology \& Pharmacology, School of Medicine, Av. Herrera Oria s/n, 39011 Santander, Spain. E-mail: hurlem@unican.es.

DOI:10.1523/JNEUROSCI.4405-13.2014

Copyright $\odot 2014$ the authors $\quad 0270-6474 / 14 / 345385-11 \$ 15.00 / 0$ maladaptive plasticity in the nervous system (Woolf and Ma, 2007; Basbaum et al., 2009). Chronic pain should be considered a disease (Cervero, 2009); it is refractory to conventional medical treatments and affects nearly $20 \%$ of the adult population (Breivik et al., 2006).

Neuropathic pain is a prevalent chronic pain syndrome (Bouhassira et al., 2008) that arises from damage to or dysfunction of the somatosensory nervous system (von Hehn et al., 2012). People with neuropathic pain may experience longlasting, altered pain sensations, such as hyperalgesia, allodynia, and spontaneous pain, which often respond poorly to treatments and, for some people, can be debilitating (Finnerup et al., 2005). Although the precise pathophysiological mechanisms are poorly understood, neuropathic pain is considered a neuroimmune disorder caused by a complex crosstalk between neurons, activated glia, and immune cells in the PNS and CNS (Milligan and Watkins, 2009; Austin and Moalem-Taylor, 2010; Calvo et al., 2012). Growth factors, inflammatory mediators, and cytokines are key players in the pathological plasticity underlying neuropathic pain (Ren and Dubner, 2010). 
The transforming growth factor- $\beta$ (TGF- $\beta$ ) family of cytokines (Wharton and Derynck, 2009; Massagué, 2012) exerts important pleiotropic regulatory effects on nociceptive transmission (Lantero et al., 2012). In particular, TGF- $\beta 1$ is a relevant mediator, providing protective effects against neuropathic pain after nerve injury. The mechanism involves inhibition of glial activation and inflammatory cytokine release, and protection against neuronal apoptosis in the spinal cord (Echeverry et al., $2009)$. In the PNS, TGF- $\beta 1$ reduces infiltration by T-lymphocyte and cytokine/chemokine secreting macrophages (Echeverry et al., 2013).

The signaling capability of TGF- $\beta$ is negatively modulated by the transmembrane protein BAMBI (BMP and activin membranebound inhibitor), a pseudoreceptor that is structurally similar to type I TGF- $\beta$-receptors but lacks the kinase domain required for phosphorylation of Smad transcription factors (Onichtchouk et al., 1999). In a previous report from our group, deletion of $B A M B I$ reveals a key inhibitory influence of TGF- $\beta$ signaling on physiological nociception and in models of inflammatory and neuropathic pathological pain (Tramullas et al., 2010). The hypoalgesic/antiallodynic phenotype of BAMBI-KO mice depends on increased activity of the endogenous opioid system after the transcriptional activation, increased expression, and synaptic release of endogenous opioid mediators (Tramullas et al., 2010; Lantero et al., 2012).

Herein, we elucidated the postsynaptic consequences of $B A M B I$ deletion on opioid receptor expression and signaling and their contribution to the antiallodynic phenotype of $B A M B I-\mathrm{KO}$ mice. We also assessed whether BAMBI deficiency affects the antinociceptive responses elicited by drugs that presynaptically and postsynaptically facilitate the opioid signals. Finally, we analyzed the involvement of opioid-related mechanisms in the antiallodynic effect of TGF- $\beta 1$.

\section{Materials and Methods \\ Animals}

$B A M B I-K O$ mice were generated by homologous recombination in a 129SvJ/C57BL6 mouse line as described previously (Tramullas et al., 2010). Mutant mice were backcrossed to the C57BL/6 strain up to the 12 th generation. Mice were maintained in heterozygosity, and the WT and $\mathrm{KO}$ mice used in our studies were the offspring from $\mathrm{BAMBI}^{+/-}$ mating couples. The experiments were performed using 14- to 18 -weekold male mice. The animals were housed in a room kept at $22^{\circ} \mathrm{C}$ and exposed for their whole lifespan to an inverted $12 \mathrm{~h}$ light $/ 12 \mathrm{~h}$ dark cycle (dark from 8:00 A.M. to 8:00 P.M.). Food and water were provided ad libitum. The study was approved by the Cantabria University Institutional Laboratory Animal Care and Use Committee, and the experiments were performed in accordance with the Declaration of Helsinki and the European Communities Council Directive (86/609/EEC) and the guidelines of the Committee for Research and Ethical Issues of International Association for the Study of Pain (Zimmermann, 1983). Every effort was made to minimize the number of animals used and their suffering.

\section{Drugs}

The dual inhibitor of enkephalinases, RB101 (N-[(R,S)-2-benzyl-3[(S)(2-amino-4-methylthio) butyldithiol]-1-oxopropyl]-L-phenylalanine benzyl ester) was provided by Dr. Bernard Roques. RB101 was dissolved in $300 \mu \mathrm{l}$ of vehicle containing ethanol (10\%), Cremophor (10\%), and distilled water $(80 \%)$. The opioid analgesic morphine was obtained from the Ministerio de Sanidad y Consumo, Gobierno de España. The opioid antagonists naloxone and methyl-naloxone were obtained from SigmaAldrich. Morphine and naloxone were dissolved in $150 \mu \mathrm{l}$ of saline. Recombinant TGF- $\beta 1$ was supplied by R\&D Systems and dissolved in 4 nм $\mathrm{HCl}$ plus $2 \mathrm{mg} / \mathrm{ml}$ albumin.

\section{Pain behavior studies}

Mice were allowed to acclimate to the environment for at least $1 \mathrm{~h}$ before testing, and the behavioral tests were performed during their activity (dark) phase, under dim red light. Behavioral testing was performed by observers blinded to the mouse genotype.

Chronic neuropathic pain behavior studies: crush injury of the sciatic nerve. Mice were subjected to sciatic nerve crush injury (Bester et al., 2000) under inhalational anesthesia with isoflurane (induction, $4 \%$; surgery, $1.5-2 \%)$. Briefly, the left common sciatic nerve was exposed via blunt dissection among two muscle bundles of the biceps femoris muscle. The sciatic nerve was isolated from surrounding connective tissue at the mid-thigh level and crushed with smooth forceps for $7 \mathrm{~s}$ just before the bifurcation of the peripheral branches, tibial, sural, and peroneal nerves. The muscle and skin layers were closed under aseptic conditions. Control cohorts (sham-operated mice) underwent the same surgical procedure, but the nerve was exposed and left intact. The time course of neuropathic pain development, manifested as mechanical hypersensitivity and tactile allodynia, was assessed before surgery and every $2 \mathrm{~d}$ after crush injury of the sciatic nerve. Animals were placed on an elevated wire grid and the plantar hindpaw stimulated using von Frey monofilaments of increasing strength $(0.07-8 \mathrm{~g})$. The results are expressed as the percentage of paw withdrawals in response to 10 applications of the stimulus. Withdrawal threshold was determined as the filament at which the animal withdrew its paw in response to at least 5 of 10 applications.

Acute chemical-inflammatory pain: formalin test. Mice received a $20 \mu \mathrm{l}$ intraplantar injection of a $2 \%$ formalin solution in the left hindpaw after which the animals were put into a Plexiglas box for the test. The time spent licking the injected paw and the number of times the paw was shaken were scored within the first 5 min (first phase) and from 20 to 60 min after the injection (second phase).

Pharmacological treatments. Mice of both genotypes subjected to sciatic nerve injury (SNI) received a single injection of RB101 $(100 \mathrm{mg} / \mathrm{kg}$, i.p.) or vehicle $30 \mathrm{~min}$ before nociceptive testing on day 28 after SNI, when mice of either genotype had developed similar levels of mechanical allodynia. In another series, mice of both genotypes received cumulative doses of morphine $(1,3,6$, and $10 \mathrm{mg} / \mathrm{kg})$ or vehicle. The hindpaw responses to mechanical stimulation were assessed $30 \mathrm{~min}$ after the administration of each dose of morphine.

Mice of both genotypes subjected to SNI received chronic vehicle $(0.24$ $\mu \mathrm{l} / \mathrm{h}$ ) or recombinant TGF- $\beta 1$ (R\&D Systems; $6.2 \mathrm{ng} / \mathrm{h}, 14 \mathrm{~d}$ ) using osmotic minipumps (Alzet 1002, Durect) implanted subcutaneously at the time of nerve surgery. The pumps deliver solutions at a constant rate of $0.24 \mu \mathrm{l} / \mathrm{h}$ for $14 \mathrm{~d}$.

In the antagonism series, either naloxone or methyl-naloxone was administered intraperitoneally at the dose of $1 \mathrm{mg} / \mathrm{kg} 30 \mathrm{~min}$ before nociceptive testing.

Mice of both genotypes subjected to the formalin test received a single injection of morphine ( 3 or $6 \mathrm{mg} / \mathrm{kg}$, i.p.) $30 \mathrm{~min}$ before the intraplantar injection of formalin.

\section{Neurochemical studies}

RNA isolation, cDNA synthesis, and real-time PCR. Total RNA from the dorsal horn of the lumbar spinal cord was obtained by TRIzol (Invitrogen) extraction. A total of $1 \mu \mathrm{g}$ of the isolated RNA was reverse transcribed into cDNA with an RT-PCR kit (Fermentas), according to the instructions of the manufacturer. Quantitative, real-time PCR was conducted on a thermocycler (Stratagene MX-3000P) using specific TaqMan expression assays (Applied Biosystems) and Universal PCR Master Mix (Takara). Specific TaqMan assays (Applied Biosystems) were used for $\mu$ - and $\delta$-opioid receptors. The results were normalized to the expression of the housekeeping gene ribosomal 18S RNA, measured in parallel in each sample. Results are expressed as $\Delta \Delta$ Ct. Duplicate transcript levels from 4 to 6 mice per group were determined in three independent experiments.

Western blot. Whole-cell lysates were prepared from the dorsal horn of the lumbar spinal cord. Equal amounts of protein were resolved on 10\% SDS-PAGE and transferred to PVDF membranes (Bio-Rad) using a Mini Trans-Blot Electrophoresis Transfer Cell (Bio-Rad). The following primary antibodies were used: anti- $\mu$-opioid receptor (1:500; Abcam), anti- 
$\delta$-opioid receptor (1:500; Santa Cruz Biotechnology), and anti-GAPDH (1:500, Santa Cruz Biotechnology). Chemiluminescence was detected with the ECL Advanced kit (GE Healthcare Europe). The films were scanned, and optical densities were determined using the Scion Image software (Scion). The results were expressed as optical density of the sample dots normalized to that obtained for GAPDH. Samples from 4 mice per group were tested in two independent experiments.

Immunofluorescence. For GFAP immunofluorescent staining, mice subjected to SNI ( $n=3$ vehicle-treated and $n=3$ TGF- $\beta$-treated) animals were perfused with PFA (3.7\% in PBS, freshly prepared) under deep pentobarbital anesthesia. The lumbar spinal cord was dissected and postfixed in PFA (3.7\% in PBS) for $12 \mathrm{~h}$. The tissue was sectioned on a vibratome $(50 \mu \mathrm{m})$. Samples free floating in PBS were treated with $0.5 \%$ Triton X-100 plus donkey serum (3\%) in PBS for $15 \mathrm{~min}$. The samples were incubated overnight at $4^{\circ} \mathrm{C}$ with a rabbit anti-GFAP polyclonal antibody (1:200; Dako). After washing in PBS, the samples were incubated with the specific secondary antibody conjugated with Texas Red (Jackson ImmunoResearch Laboratories) and washed and mounted in VectaShield (Vector Laboratories). Omission of primary or secondary antibodies completely abolished specific staining. Confocal microscopy was performed with an LSM-510 laser scanning microscope (Carl Zeiss).

cAMP assay. The assays were performed as described previously (Valdizán et al., 2012) with some variations. A total of $50 \mathrm{mg}$ of spinal cord samples was homogenized (1:60-1:90 weight/volume dilution) in an ice-cold homogenization buffer (20 mM Tris-HCl, 1 mM EGTA, 5 mM EDTA, $1 \mathrm{~mm}$ DTT, $25 \mu \mathrm{g} / \mathrm{ml}$ leupeptin, and $300 \mathrm{~mm}$ sucrose, $\mathrm{pH}$ 7.4). The homogenates were centrifuged at $1500 \times \mathrm{g}\left(5 \mathrm{~min}\right.$ at $\left.4^{\circ} \mathrm{C}\right)$, and the resulting supernatants were centrifuged at $13,000 \times \mathrm{g}\left(15 \mathrm{~min}\right.$ at $\left.4^{\circ} \mathrm{C}\right)$. The pellets were resuspended in homogenization buffer. A total of $50 \mathrm{mg}$ of protein was preincubated for $5 \mathrm{~min}$ at $37^{\circ} \mathrm{C}$ in assay buffer $(80 \mathrm{~mm}$ Tris-HCl, 0.2 mм EGTA, 1 mм EDTA, 2 mu $\mathrm{MgCl}_{2}, 100 \mathrm{~mm} \mathrm{NaCl}, 60 \mathrm{~mm}$ sucrose, 1 mм DTT, 10 mM GTP, 0.5 mm IBMX, 5 mm phosphocreatine, $50 \mathrm{U} / \mathrm{ml}$ creatine phosphokinase, and $5 \mathrm{U} / \mathrm{ml}$ myokinase, $\mathrm{pH}$ 7.4) without (basal AC activity) or with $10 \mathrm{~mm}$ forskolin (FK; FK-stimulated cAMP accumulation). Opioid receptor-mediated inhibition of FKstimulated cAMP accumulation was determined using the $\mu$-agonist $\operatorname{DAMGO}\left(10^{-5} \mathrm{M}\right)$ and the $\delta$-agonist DPDPE $\left(10^{-5} \mathrm{M}\right)$. The specificity of the effects was determined by adding selective opioid antagonists $(\mu$ : $\beta$-funaltrexamine; $\delta$ : naltrindole) to the medium at a concentration of $10^{-4} \mathrm{M}$. In all the experimental conditions, Mg-ATP $0.2 \mathrm{mM}$ was added to the membranes, and the mixture was incubated for $10 \mathrm{~min}$ at $37^{\circ} \mathrm{C}$. The reaction was stopped by boiling for $5 \mathrm{~min}$, and the cAMP concentration was determined in a $50 \mu \mathrm{l}$ sample of the supernatant using a commercial kit (TRK 432, GG; GE Healthcare Pharmacia Biotech U.K. Limited). Assays were performed using 4-10 samples per group in triplicate. Each sample was analyzed in two independent experiments. The results are expressed as $\mathrm{pmol}$ of $\mathrm{cAMP} / \mathrm{min} / \mathrm{mg}$ protein.

\section{Data analysis and statistics}

Behavioral experiments were conducted blindly both to the treatment and to the genotype of the mice. Significant differences between groups were analyzed with one-way, two-way, or repeated-measures ANOVA, as appropriate, followed by Bonferroni's post hoc test. Independent-sample $t$ tests were used to compare two independent groups. All tests were performed at a significance level of $p<0.05$. All analyses were performed using SPSS 20.0 for Windows. All graphs show the mean values \pm SEM.

\section{Results}

Neurochemical consequences of $B A M B I$ deficiency in opioid receptor signaling

We have previously reported that an absence of the inhibitory influence of BAMBI in knock-out mice results in a gain in TGF- $\beta$ signaling in the CNS (Tramullas et al., 2010). As a result, BAMBIdeficient mice display a hypoalgesic and antiallodynic phenotype associated with increased production of $\beta$-endorphin and enkephalin opioid peptides. Accordingly, the phenotype was completely reversed by selective antagonists of $\mu$ - and $\delta$-opioid receptors. Here, we tested the hypothesis that postsynaptic changes in $\mu$-and $\delta$-opioid receptor signaling could also contribute to the antiallodynic phenotype of BAMBI-KO mice. For this purpose, $\mu$ - and $\delta$-opioid receptor expression and signaling through the adenylyl cyclase pathway were determined in the lumbar spinal cord from mice subjected to sciatic SNI. The experiments were performed on day 14 after SNI, when mice exhibited maximal differences between genotypes in the degree of mechanical allodynia developed (i.e., WT mice developed allodynia while $B A M B I-K O$ mice did not).

\section{BAMBI-deficient mice subjected to SNI exhibited upregulation of} $\mu$-and $\delta$-opioid receptors in the lumbar spinal cord

The $\mu$ - and $\delta$-opioid receptor mRNA and protein expression levels were determined in the lumbar spinal cord by qPCR and Western blot, respectively. As shown in Figure $1 A, B$, on day 14 after SNI, $B A M B I-\mathrm{KO}$ exhibited a significant increase in the transcript levels of both $\mu$ - ( $n=4$ or 5 per group; two-way ANOVA: genotype, $F_{(1,15)}=35.7, p<0.001$; nerve injury, $F_{(1,15)}=39.0$, $p<0.001$; genotype $\times$ nerve injury, $\left.F_{(1,15)}=35.5, p<0.001\right)$ and $\delta$-opioid receptors ( $n=5$ or 6 per group; two-way ANOVA: genotype, $F_{(1,22)}=20.5, p<0.001$; nerve injury, $F_{(1,22)}=24.2$, $p<0.001$; genotype $\times$ nerve injury, $\left.F_{(1,22)}=18.7, p<0.001\right)$ compared with sham $B A M B I-\mathrm{KO}$ mice, whereas no significant changes in the gene expression of opioid receptors were observed in the WT group. The increased expression of both receptor types in KO mice subjected to SNI was confirmed at the protein level (Fig. $1 C, D$ ) by Western blot experiments [ $\mu$-opioid receptor $\left(n=4\right.$ per group; two-way ANOVA: genotype, $F_{(1,12)}=7.0, p<$ 0.05 ; genotype $\times$ nerve injury, $\left.F_{(1,12)}=4.8, p<0.05\right)$ and $\delta$-opioid receptors $(n=4$ per group; two-way ANOVA: genotype, $F_{(1,12)}=7.1, p<0.05$; genotype $\times$ nerve injury, $F_{(1,12)}=$ 5.0, $p<0.05)$ ]. Thus, our findings indicate that, after SNI, $B A M B I-K O$ mice upregulated $\mu$ - and $\delta$-opioid receptors in the lumbar spinal cord, whereas WT animals did not.

The absence of BAMBI potentiated the inhibitory effect of $\mu$ - and $\delta$-opioid agonists on forskolin-induced cAMP accumulation in the spinal cord of mice subjected to SNI

The adenylyl cyclase (AC)/cAMP pathway is most likely the best characterized effector system linked to opioid receptor signaling (Law et al., 2000). After receptor activation, the signal to inhibit AC is mainly transduced by pertussis toxin-sensitive $\left(\mathrm{G} \alpha_{\mathrm{i}}\right)$ and insensitive $\left(\mathrm{G} \alpha_{\mathrm{z}}\right) \mathrm{G}$-protein subunits, resulting in reduced cAMP production (George et al., 2000). We assessed whether BAMBI deficiency strengthened the opioid receptor-mediated inhibition of AC in lumbar spinal cord membranes. On day 14 after SNI, $\mathrm{WT}$ and $B A M B I-\mathrm{KO}$ mice showed similar basal AC activity $\left(8.9 \pm 0.9\right.$ and $8.4 \pm 1.7 \mathrm{pmol} \cdot \mathrm{min}^{-1} \cdot \mathrm{mg}$ protein ${ }^{-1}$; WT and $\mathrm{KO}$, respectively) and forskolin-stimulated cAMP production $(29.4 \pm 3.3 \%$ and $29.3 \pm 7.1 \%$ stimulation; WT and $\mathrm{KO}$, respectively). Incubation of the membranes with the selective $\mu$-opioid agonist DAMGO $\left(10^{-5} \mathrm{M}\right)$, or with the $\delta$-opioid agonist DPDPE $\left(10^{-5} \mathrm{M}\right)$, reduced the accumulation of cAMP after stimulation by forskolin in mice of both genotypes (Fig. 2). After nerve injury, the inhibitory response to DAMGO was significantly reduced in the WT group, and the responses to both opioid agonists were significantly higher in the SNI-KO than in the SNI-WT group [DAMGO: $n=9$ or 10 per group; two-way ANOVA, genotype $\times$ nerve injury, $F_{(1,36)}=6.1, p<0.05$; DPDPE: $n=4$ per group; two-way ANOVA, genotype, $\left.F_{(1,12)}=8.6, p<0.05\right]$. 
Functional consequences of $B A M B I$

deficiency on the antinociceptive responses induced by drugs affecting the opioid system

We assessed whether the neurochemical phenotype produced by $B A M B I$ deficiency would determine changes in the antinociceptive and/or antiallodynic responses induced by analgesic drugs that facilitate opioid signaling either presynaptically or postsynaptically.

\section{$B A M B I$ deficiency enhanced the} antinociceptive response to the inhibitor of enkephalinases, RB101, in neuropathic and inflammatory pain models

An increased presence of endogenous opioid peptides in nociception relevant areas is involved in the hypoalgesic phenotype of BAMBI-deficient mice (Tramullas et al., 2010). Therefore, we postulated that increasing the lifetime of synaptically released opioid peptides, by inhibiting their inactivating enzymes, would potentiate the hypoalgesic phenotype. Thus, we assessed the influence of $B A M B I$ deficiency on the antinociceptive effect of RB101, a systemically active inhibitor of metallopeptidases (Fournié-Zaluski et al., 1992) that produces a large increase in extracellular levels of enkephalins (Daugé et al., 1996; Le Guen et al., 2003).

Under basal conditions (i.e., shamoperated mice), RB101 (100 mg/kg, i.p.) reduced the paw withdrawal responses to mechanical stimuli only in BAMBI-KO mice ( $n=3$ or 4 per group; repeatedmeasures two-way ANOVA, genotype, $F_{(1,10)}=35.9, p<0.001$; treatment, $F_{(1,10)}$ $=5.7, p<0.05$; genotype $\times$ treatment, $\left.F_{(1,10)}=4.1, p<0.05\right)$, whereas the WT mice were insensitive to the inhibitor of enkephalinases (Fig. $3 A, B$ ). The influence of the genotype on the antiallodynic effect of RB101 was also determined in mice subjected to SNI. The inhibitor of enkephalinases was injected on day 28 after nerve injury, when mice of both genotypes had developed similar levels of mechanical allodynia (Fig. $3 F$ ). The hindpaw withdrawal response to mechanical stimulation with von Frey monofilaments was assessed $30 \mathrm{~min}$ after drug administration. Under these experimental conditions, RB101 significantly reduced the allodynic responses triggered by mechanical stimuli (Fig. 3C,D) in mice of both genotypes. However, the antiallodynic effect of RB-101 was significantly higher in BAMBI-KO mice than in WT mice (repeated-measures two-way ANOVA, $n=4$ or 5 per group; treatment, $F_{(1,13)}=103.4, p<0.001$; genotype, $F_{(1,13)}=$ $182, p<0.001$; treatment $\times$ genotype, $\left.F_{(1,13)}=16.6, p<0.001\right)$.

Coadministration of the opioid antagonist naloxone $(1 \mathrm{mg} /$ $\mathrm{kg}$ ) with RB101 to $B A M B I-\mathrm{KO}$ mice completely prevented the antiallodynic effect of $\mathrm{RB} 101 \quad(n=5$ per group; one-way ANOVA, $F_{(2,14)}=6.3 p<0.01$; Fig. $3 E$ ). The analgesic potency of the peptidase inhibitors depends directly on the magnitude of the receptor.

\section{B $\delta$-opioid receptor}

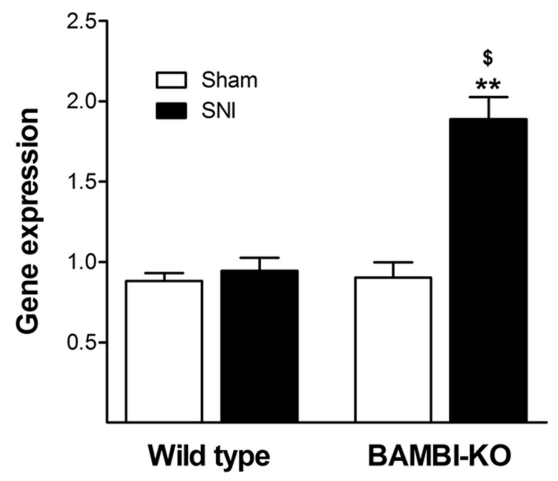

D

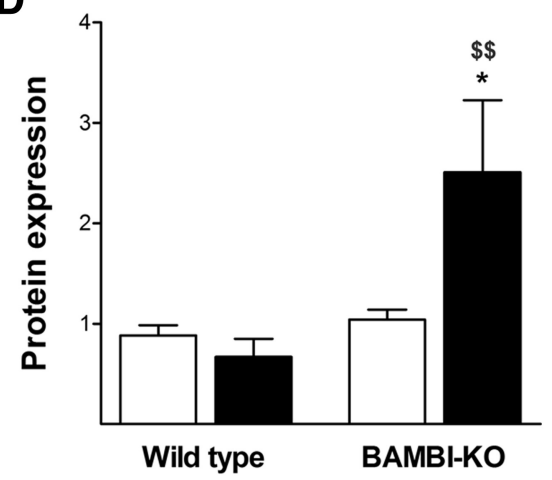

D’

Sham SNI Sham SNI

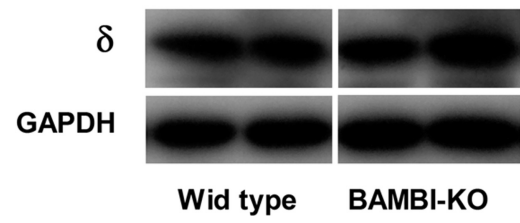

Figure 1. Gene and protein expression levels of $\mu$ - and $\delta$-opioid receptors in the lumbar spinal cord from wild-type and $B A M B I-K 0$ mice subjected to $S N I$ or sham operated. Gene expression $(\boldsymbol{A}, \boldsymbol{B})$ was determined by $q \mathrm{PCR}$ and normalized to $18 \mathrm{~S}$. Protein (tw0-way ANOVA followed by Bonferroni's post hoc test). ${ }^{* *} p<0.01$, SNI-KO versus Sham-KO (two-way ANOVA 政 est). $p<0.05$, SNI-KO versus SNI-wild-type (two-way ANOVA followed by Bonferroni's posthoc test). ${ }^{\$ \$} p<0.01$, SNI-KO versus SNI-wild-type (two-way ANOVA followed by Bonferroni's post hoc test). ${ }^{\$ \$ \$} p<0.001$, SNI-KO versus SNI-wild-type (two-way

extracellular release of endogenous opioid peptides (Noble et al., 2008). Thus, our results are in agreement with the higher expression levels of endogenous opioid peptides in the spinal cord of $B A M B I-\mathrm{KO}$, compared with WT mice, as previously reported by our group (Tramullas et al., 2010).

The antinociceptive effect of RB101 was also assessed in the formalin test of chemical/inflammatory pain (Fig. 4). Typically, the intradermal injection of formalin into the plantar surface of the hindpaw produced a biphasic paw-licking response; the first phase (first $5 \mathrm{~min}$ ) is thought to result from direct activation of primary afferent sensory neurons, whereas the second phase (20-60 $\mathrm{min}$ ) has been proposed to reflect the combined effects of afferent input and activity-dependent sensitization of CNS neurons within the dorsal horn (Coderre et al., 1990; Tjølsen et al., 1992; McNamara et al., 2007).

Mice were treated with RB101 (100 mg/kg, i.p.) or vehicle 30 min before receiving a $20 \mu \mathrm{l}$ intraplantar injection of formalin in 
A
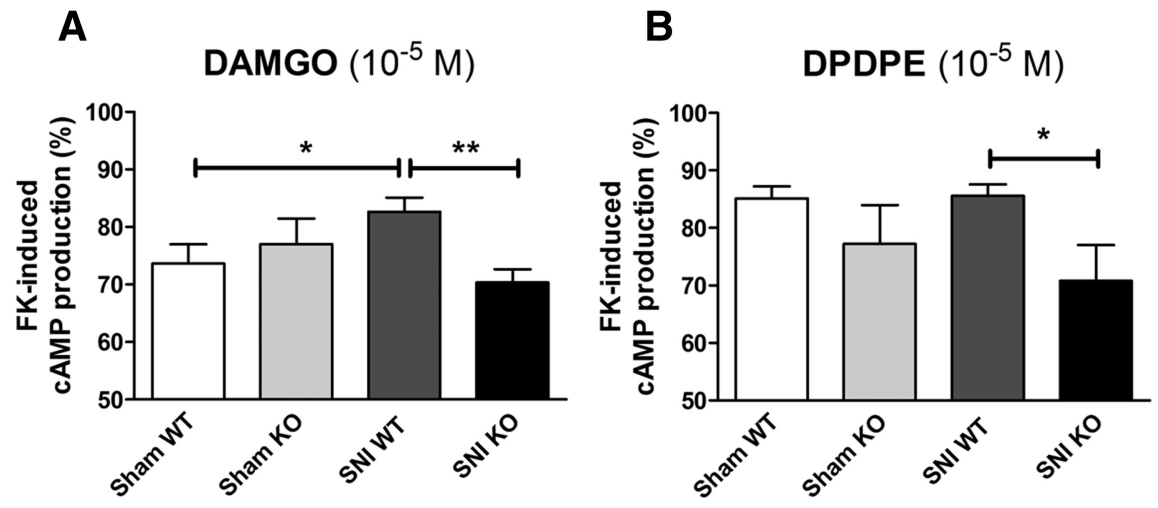

Figure 2. Opioid receptor-mediated inhibition of forskolin-induced cAMP accumulation in spinal cord homogenates. The data represent the percentage (mean \pm SEM) offorskolin (FK)-stimulated cAMP accumulation (100\%) in the presence of the $\mu$-agonist DAMGO $(\boldsymbol{A})$ or the $\delta$-opioid agonist DPDPE $(\boldsymbol{B})$, in lumbar spinal cord membranes obtained from WT and BAMBI-KO mice subjected to SNI or sham operated. ${ }^{*} p<0.05$, SNI-WT versus SNI-KO (tw0-way ANOVA followed by Bonferroni's post hoc test). ${ }^{* *} p<0.01$, SNI-WT versus SNI-KO (two-way ANOVA followed by Bonferroni's post hoc test).

the left hindpaw. The time spent licking the paw was recorded within the first $5 \mathrm{~min}$ (first phase) and from 20 to $60 \mathrm{~min}$ after injection (second phase). The antinociceptive response (licking time) to RB101 (Fig. 4) was significantly lower in BAMBI-KO than in WT mice in both phases of the test $(n=6$ per group, first phase, two-way ANOVA: genotype, $F_{(1,20)}=74.1, p<0.001$; treatment, $F_{(1,20)}=59.0, p<0.001$; genotype $\times$ treatment, $F_{(1,20)}$ $=4.6, p<0.05)$; second phase: genotype, $F_{(1,20)}=140.8 p<$ 0.001 ; treatment, $F_{(1,20)}=44.3, p<0.001$; genotype $\times$ treatment, $\left.F_{(1,20)}=8.0, p<0.05\right)$. As we have previously shown (Tramullas et al., 2010), vehicle-treated BAMBI-KO mice exhibited significantly reduced pain behaviors in both phases of the test (Fig. 4) compared with their WT littermates.

$B A M B I$ deficiency enhanced the antinociceptive response to morphine in neuropathic and inflammatory pain models

Cumulative doses of the opioid agonist morphine (1, 3, 6, and 10 $\mathrm{mg} / \mathrm{kg}$ ) or vehicle were administered every $40 \mathrm{~min}$ to mice of both genotypes, either sham operated or subjected to SNI, on day 28 after nerve injury, when SNI mice of both genotypes had developed similar levels of mechanical allodynia (Fig. $3 F$ ). The hindpaw withdrawal responses to mechanical stimulation with von Frey monofilaments were assessed $30 \mathrm{~min}$ after the administration of each dose of morphine. The elapsed time between the first and the last morphine dose was $150 \mathrm{~min}$.

Morphine significantly reduced the paw withdrawal responses to mechanical stimuli of increasing strength in sham-operated mice of both genotypes (Fig. 5). However, the inhibitory effects on the paw withdrawal responses to mechanical stimuli of 3 and $6 \mathrm{mg} / \mathrm{kg}$ of morphine were significantly higher in the BAMBI-KO group than in WT $[n=5-6$ per group, repeated-measures twoway ANOVA, $1 \mathrm{mg} / \mathrm{kg}$ (genotype: $F_{(1,19)}=21.1, p<0.001$, treatment: $\left.F_{(1,19)}=6.1, p<0.001\right) ; 3 \mathrm{mg} / \mathrm{kg}$ (genotype: $F_{(1,19)}=30.8$, $p<0.001$; treatment: $F_{(1,19)}=58.8, p<0.001$; genotype $\times$ treatment: $\left.F_{(1,19)}=6.4, p<0.05\right) ; 6 \mathrm{mg} / \mathrm{kg}$ (genotype: $F_{(1,19)}=37.8$, $p<0.001$; treatment: $F_{(1,19)}=75.5, p<0.001$; genotype $\times$ treatment: $\left.F_{(1,19)}=5.5, p<0.05\right) ; 10 \mathrm{mg} / \mathrm{kg}$ (genotype: $F_{(1,19)}=14.2$, $p<0.001$; treatment: $\left.\left.F_{(1,19)}=544.1, p<0.001\right)\right]$.

WT mice suffering from neuropathic pain were resistant to the antinociceptive effect of morphine, as they only responded to the highest dose of the opioid tested $(10 \mathrm{mg})$. On the other hand, as shown in Figure 6, BAMBI-KO mice were significantly more sensitive to the antiallodynic effect of 3 and $6 \mathrm{mg} / \mathrm{kg}$ of morphine $[n=6$ mice per group, repeated-measures one-way ANOVA, morphine $3 \mathrm{mg} / \mathrm{kg}$ (genotype: $F_{(1,20)}=7.5, p<0.05$; force: $F_{(2,20)}=72.5, p<0.001$, force $\times$ treatment: $\left.F_{(2,20)}=5.1, p<0.05\right)$; morphine 6 $\mathrm{mg} / \mathrm{kg}$ : (genotype: $F_{(1,20)}=6.3, p<0.05$; force: $F_{(2,20)}=37.6, p<0.001$, genotype $\times$ force: $\left.\left.F_{(2,20)}=6.9, p<0.01\right)\right]$.

The antinociceptive effect of morphine was also assessed in the formalin test (Fig. 7 ). Mice were treated with morphine (3 and $6 \mathrm{mg} / \mathrm{kg}$ ) or saline, $30 \mathrm{~min}$ before the intraplantar injection of formalin in the hindpaw. The time spent licking the paw was recorded during the first $5 \mathrm{~min}$ and from 20 to $60 \mathrm{~min}$ after injection. During the first phase of the test, in mice of both genotypes, morphine reduced the time spent licking the paw after formalin injection (Fig. 7), although the antinociceptive response was significantly higher in $B A M B I-\mathrm{KO}$ than in WT mice in both phases of the test [first phase: $n=6$ or 7 mice per group, two-way ANOVA: genotype: $F_{(1,37)}=43.0, p<0.001$; treatment: $F_{(2,37)}=29.5, p<0.001$; genotype $\times$ treatment: $F_{(2,37)}=3.35, p<0.05$; second phase: genotype: $F_{(1,37)}=106.0, p<0.001$; treatment: $F_{(2,37)}=301.4$, $p<0.001$; genotype $\times$ treatment: $\left.F_{(2,37)}=21.8, p<0.001\right]$.

\section{Participation of the opioid system in the antiallodynic responses induced by recombinant TGF- $\beta 1$ in an experimental model of neuropathic pain}

Chronic intrathecal infusion of recombinant TGF- $\beta 1$ attenuates neuropathic pain behaviors by a mechanism involving the inhibition of deleterious spinal cord neuroimmune responses to peripheral nerve injury in rats (Echeverry et al., 2009). In addition, we previously showed that the endogenous opioid precursors are under the transcriptional control by TGF- $\beta$ signaling in the spinal cord (Tramullas et al., 2010). Here, we hypothesized that the activity of the endogenous opioid system could contribute to the antiallodynic effect of TGF- $\beta 1$. To test this hypothesis, a series of wild-type mice received a $14 \mathrm{~d}$ infusion of recombinant TGF- $\beta 1$ ( $5 \mu \mathrm{g} / \mathrm{kg} / \mathrm{d}$ ) or vehicle, starting on the day of SNI. Given that previous reports demonstrate the capacity of TGF- $\beta$ s to cross the blood-brain barrier (McLennan et al., 2005), the osmotic minipumps were implanted subcutaneously. Using von Frey monofilaments, mice were assessed for mechanical allodynia development every second day. As shown in Figure 8, mice treated with recombinant TGF- $\beta 1$ displayed an attenuated allodynic response compared with vehicle-treated mice $(n=6-8$ mice per group, repeated-measures two-way ANOVA, treatment: $F_{(1,25)}=12.2, p<0.01$; force $\times$ treatment: $F_{(9,225)}=4.6$, $p<0.001)$. The administration of an acute dose of naloxone ( 1 $\mathrm{mg} / \mathrm{kg}$ ), $30 \mathrm{~min}$ before performing the von Frey test on day 14 after nerve injury completely reverses the antiallodynic effect of TGF- $\beta 1$ (Fig. 8A). To assess the potential contribution of peripheral opioid-related mechanisms to the analgesic effect of subcutaneous TGF- $\beta 1$, mice were treated with $N$-methylnaloxone ( 1 $\mathrm{mg} / \mathrm{kg}$ ), a quaternary derivative of naloxone that does not cross the blood-brain barrier. As shown in Figure $8 B$, administration of methylnaloxone 30 min before performing the von Frey test on day 14 after nerve injury did not antagonize the antiallodynic effect of TGF- $\beta 1$ ( $n=6$ per group, one-way ANOVA, $F_{(2,17)}=$ 
14.5, $p<0.001$ ), indicating that the effect was fully dependent on central opioid pathways.

As mentioned above, Echeverry et al. (2009) link the antiallodynic effect of intrathecal TGF- $\beta 1$ to an attenuated spinal cord glial response after peripheral neuropathy. We therefore analyzed by immunofluorescence the changes in glial proliferation using GFAP, an astrocyte marker, $14 \mathrm{~d}$ after SNI in L4-L5 spinal cord sections. In mice treated with vehicle, an increase in GFAP immunoreactivity was observed within the ipsilateral spinal cord $14 \mathrm{~d}$ after nerve injury (Fig. 9). The treatment with a subcutaneous infusion of TGF- $\beta 1$ for $14 \mathrm{~d}$ consistently reduced the increase in GFAP immunoreactivity (Fig. 9), which indicates a protective effect against astrocyte reaction.

\section{Discussion}

Neuropathic pain is a chronic debilitating disease characterized by mechanical allodynia and spontaneous pain. Because symptoms are often unresponsive to conventional treatments, new therapeutic approaches are essential. Herein, we demonstrated the potential of TGF- $\beta$ signaling modulation as an alternative strategy to alleviate pathological pain by a mechanism exploiting the endogenous, opioidmediated, pain-inhibitory circuits.

Downstream transduction of TGF- $\beta$ signals after ligand binding is prevented by the kinase-deficient decoy-receptor BAMBI (Onichtchouk et al., 1999). Deletion of the $B A M B I$ gene has constituted an effective strategy for unraveling the involvement of the TGF- $\beta$ family in the control of pain states. BAMBI-KO mice show a hypoalgesic phenotype that involves increased transcription and synaptic release of endogenous opioids that include enkephalins and $\beta$-endorphin (Tramullas et al., 2010).

Our present findings indicate that TGF- $\beta$ signaling not only improves the functionality of the endogenous opioid system at the presynaptic level but also postsynaptically regulates the expression and function of opioid receptors. Thus, two weeks after SNI, when WT mice had already developed mechanical allodynia but $B A M B I-\mathrm{KO}$ mice had not, $B A M B I-$ deficient mice exhibited upregulation of $\mu$-and $\delta$-opioid receptors in the lumbar spinal cord, whereas no significant changes in opioid receptor density were evident in the WT group. Receptor expression regulation is a well-documented phenomenon in the opioid system and can have an impact on cellular responses to agonists (Mostany et al., 2008). Adenylyl cyclase is a major intracellular effector linked to opioid receptor activity whose inhibition by agonists

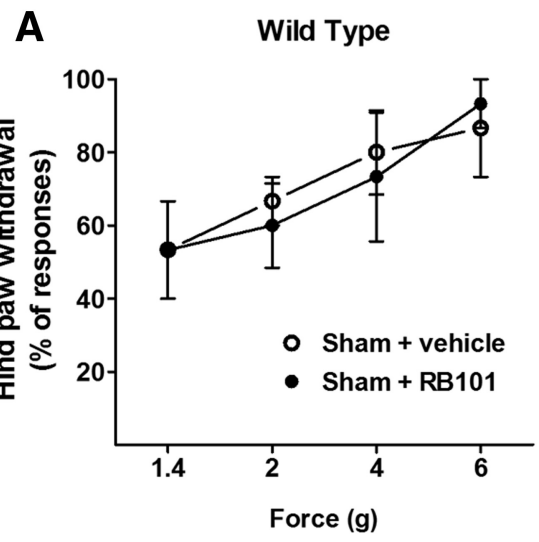

B

BAMBI-KO

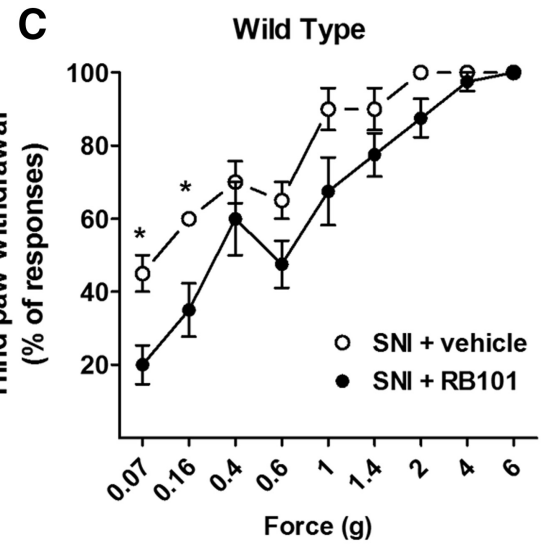

E Sciatic injury BAMBI-KO

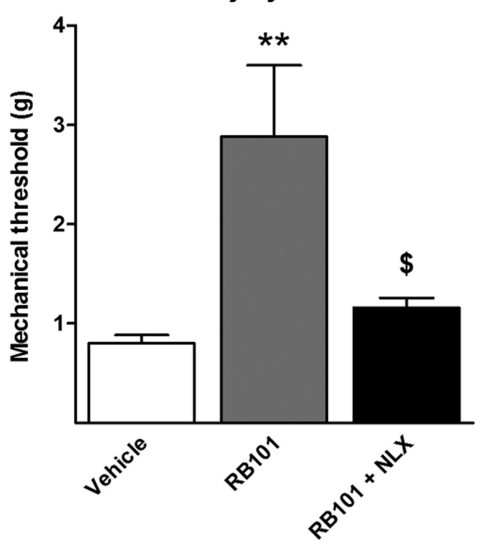

$\mathbf{F}$
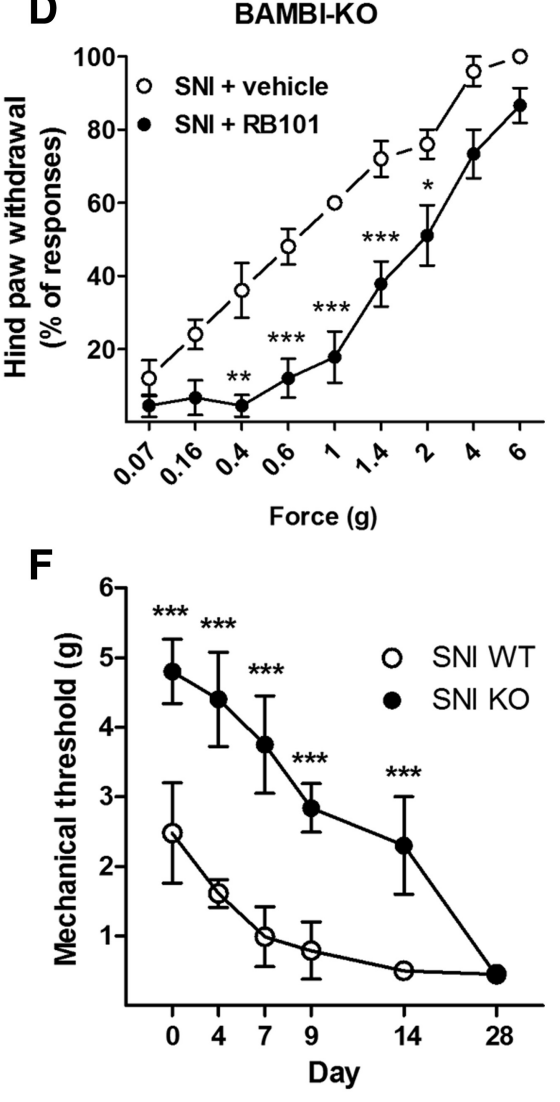

Figure 3. Effect of the inhibitor of enkephalinases, RB101, on the responsiveness of the hindpaw to mechanical stimulation with von Frey monofilaments. Representative graphs showing the percentage of paw withdrawal responses to stimuli of increasing strength in wild-type $(\boldsymbol{A}, \boldsymbol{C})$ and $B A M B I-K 0$ mice $(\boldsymbol{B}, \boldsymbol{D})$, sham operated or subjected to the neuropathic pain condition by $\mathrm{SNI}$, treated with vehicle (open circles) or with RB101 (filled circles) 30 min before performing the test. ${ }^{*} p<0.05$, versus vehicle (repeated-measures two-way ANOVA followed by Bonferroni's post hoc test). ${ }^{* *} p<0.01$, versus vehicle (repeated-measures two-way ANOVA followed by Bonferroni's posthoc test). ${ }^{* *} p<0.001$, versus vehicle (repeated-measures two-way ANOVA followed by Bonferroni's post hoc test). $\boldsymbol{E}$, Effect of coadministration of the opioid antagonist naloxone (NLX, $1 \mathrm{mg} / \mathrm{kg}$, i.p.) with RB101 on the mechanical sensitivity threshold in BAMBI-KO mice subjected to SNI. ${ }^{*} p<0.05$, versus vehicle (one-way ANOVA followed by Bonferroni's post hoc test). ${ }^{5} p<0.05$, versus RB101 alone (one-way ANOVA followed by Bonferroni's post hoc test). $\boldsymbol{F}$, Representative time course of mechanical threshold of WT and K0 mice subjected to SNI. ${ }^{* * *} p<0.001$, versus WT (Student's $t$ test). Data are mean \pm SEM.

results in reduced cAMP production (Law et al., 2000; Valdizán et al., 2012). This pathway plays a crucial role in antinociception mediated by opioid drugs and other pharmacological agents (Kim et al., 2006; Pierre et al., 2009). Here we show that, after SNI, the inhibitory effects of the $\mu$-agonist DAMGO and the $\delta$-agonist DPDPE on forskolin-induced cAMP accumulation were significantly enhanced in $B A M B I-K O$ mice, at a time point at which, 

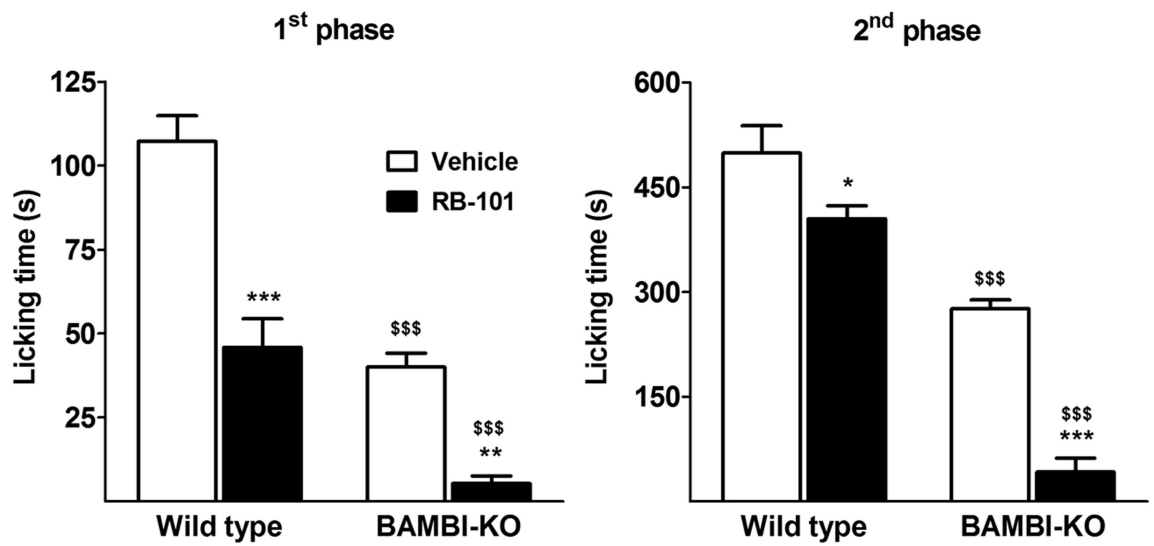

Figure 4. Antinociceptive effect of RB101 in the formalin test of chemical/inflammatory pain. Mice received RB101 30 min before the subcutaneous injection of formalin into the plantar surface of the left hindpaw. Data are the cumulative time spent licking the paw after formalin injection, from 0 to 5 min (first phase) and from 20 to 60 min after injection (second phase). ${ }^{\$ \$ \$} p<$ $0.001, B A M B I-K 0$ versus WT (two-way ANOVA followed by Bonferroni's post hoc test). ${ }^{*} p<0.05, \mathrm{RB}-101$ versus vehicle (two-way ANOVA followed by Bonferroni's post hoc test). ${ }^{* *} p<0.01$, RB-101 versus vehicle (two-way ANOVA followed by Bonferroni's post hoc test). ${ }^{* *} p<0.001$, RB-101 versus vehicle (two-way ANOVA followed by Bonferroni's post hoc test).

A

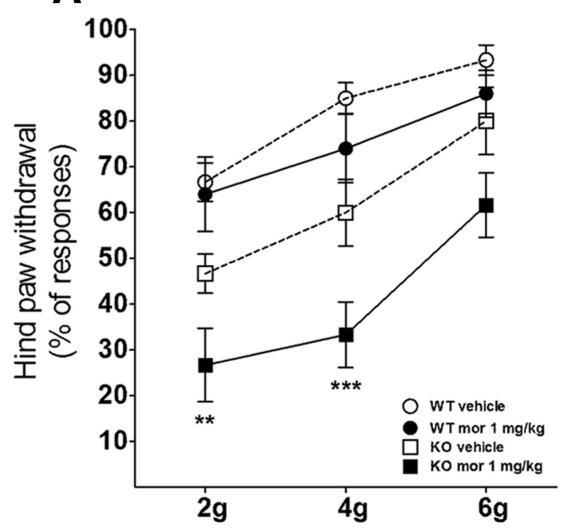

C

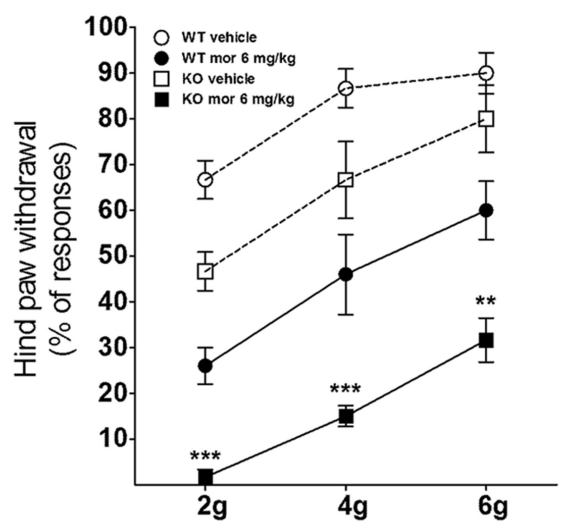

B
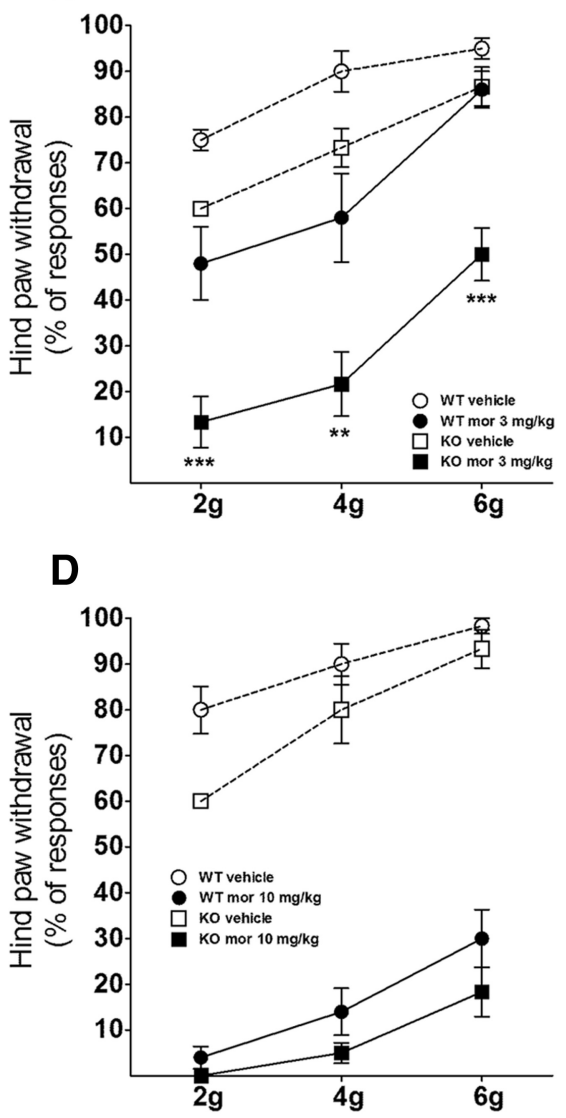

Figure 5. Effect morphine on the hindpaw responsiveness to mechanical stimulus in sham-operated WT and BAMBI-KO mice. Mice of either genotype received cumulative doses of morphine (mor) or vehicle, every $45 \mathrm{~min}$. Mice were tested for mechanical responsiveness with von Frey monofilaments 30 min after receiving each morphine dose $(\boldsymbol{A}, 1 \mathrm{mg} / \mathrm{kg} ; \boldsymbol{B}, 3 \mathrm{mg} / \mathrm{kg} ; \boldsymbol{C}, 6 \mathrm{mg} / \mathrm{kg} ; \boldsymbol{D}, 10 \mathrm{mg} / \mathrm{kg})$. The data are expressed as the mean \pm SEM. ${ }^{* *} p<0.01, B A M B I-W T$ versus BAMBI-KO (repeated-measures two-way ANOVA followed by Bonferroni's post hoc test). ${ }^{* * *} p<0.001, B A M B I-W T$ versus BAMBI-KO (repeated-measures two-way ANOVA followed by Bonferroni's post hoc test).

unlike the WT group, KO mice did not exhibit allodynia. Overall, these results indicate that, after SNI, the overexpression of functional opioid receptors developed by BAMBI-KO mice contributed to their antiallodynic phenotype by increasing the anti- nociceptive potential of enkephalins and $\beta$-endorphin. This proposal is consistent with the high expression levels of BAMBI and several Type I TGF- $\beta$ receptors in opioid receptor-rich areas, such as the cingulate cortex, the periaqueductal gray region, and the dorsal horn of the spinal cord (Tramullas et al., 2010), which are part of the endogenous pain inhibitory circuitry (Ossipov et al., 2010).

Many studies indicate that enkephalins cause both presynaptic and postsynaptic inhibition of incoming Type $\mathrm{C}$ and A $\delta$ pain fibers, which synapse in the dorsal horn of the spinal cord to cause an opioidlike antinociceptive effect (Yaksh et al., 1982). Targeted delivery and expression of PENK in the nervous system by gene transfer are one effective strategy to produce analgesia by increasing the release of enkephalins in the spinal cord (Goss et al., 2001; Hao et al., 2003; Fink et al., 2011). Consistent with this, PENK deficiency produces exaggerated behavioral responses to painful stimuli in mice (König et al., 1996). The enkephalins undergo rapid breakdown in the synapses because of the concomitant action of two zincmetallopeptidases, the neutral endopeptidase neprilysin and aminopeptidase $\mathrm{N}$. RB101 is a systemically active dual inhibitor of both metalloproteinases (FourniéZaluski et al., 1992, Noble et al., 1992), which induces antinociceptive responses in normal and neuropathic rats by increasing the lifetime of synaptic enkephalins (Daugé et al., 1996; Le Guen et al., 2003; Roques et al., 2012). In the present study, the antinociceptive effect of RB101 was significantly higher in BAMBI-KO than in WT mice at baseline, as well as under conditions of chemical/inflammatory pain (formalin test) and neuropathic allodynia. Moreover, the opioid antagonist naltrexone completely reversed the antiallodynic effect of RB101 in BAMBI-KO mice. It is known that the analgesic potency of peptidase inhibitors depends directly on the magnitude of the extracellular release of endogenous opioid peptides (Roques et al., 2012). Therefore, our results further support the hypothesis that increased synaptic release of enkephalins is a significant contributor to the hypoalgesic/antiallodynic phenotype of BAMBI-KO mice.

Our next objective was to assess whether the analgesic effect of exogenous opioids is potentiated by BAMBI deficiency. From a clinical point of view, this question is highly important because, although opioid drugs are the most efficacious agents currently available for treatment of moderate to severe pain, inadequate analgesia is sometimes achieved at levels of opioid therapy that cause intolerable side 
A

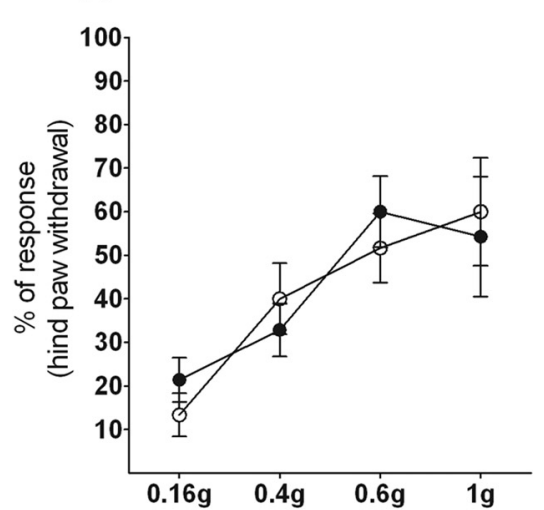

B

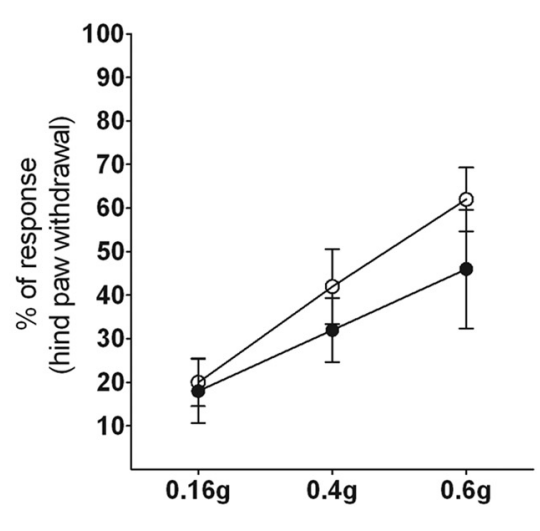

C Morphine $3 \mathrm{mg} / \mathrm{kg}$

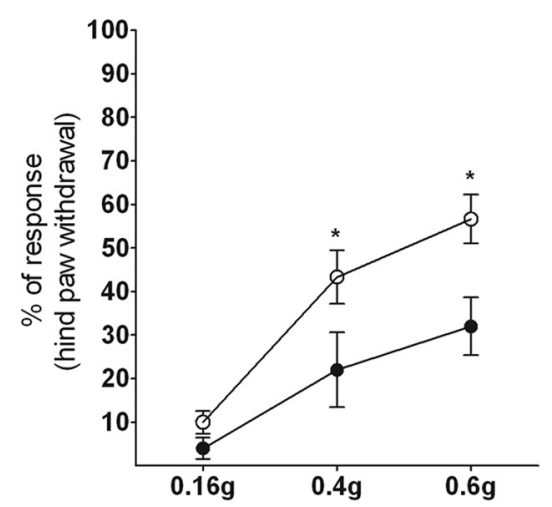

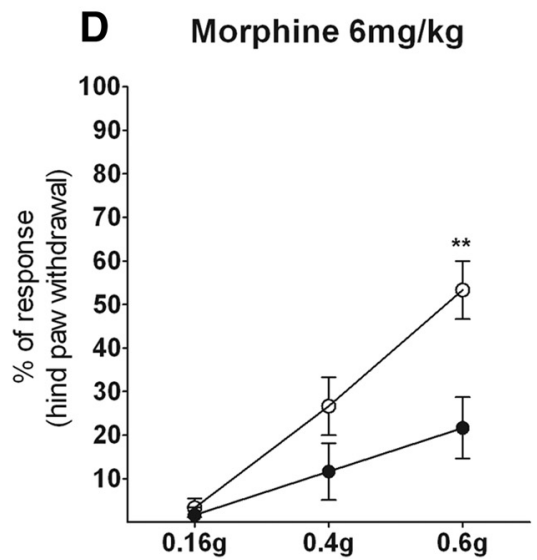

\section{E Morphine $10 \mathrm{mg} / \mathrm{kg}$}

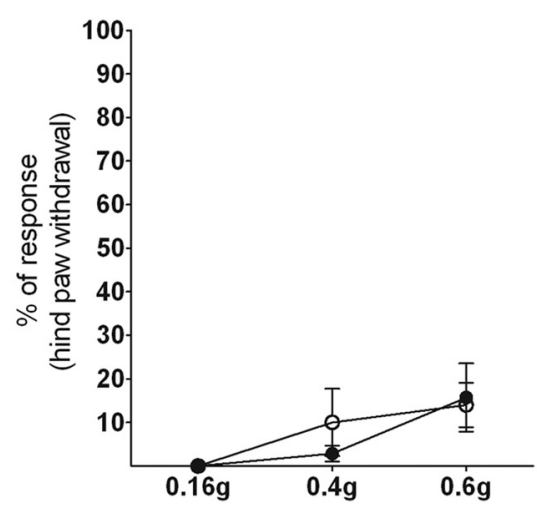

Figure 6. Antiallodynic effect of morphine in mice subjected to SNI. Wild-type (open circles) and BAMBI-KO mice (filled circles), subjected to SNI, received cumulative doses of the opioid agonist morphine $(1,3,6$, and $10 \mathrm{mg} / \mathrm{kg})$ on day 28 after injury, when mice of both genotypes had developed similar levels of mechanical allodynia. The hindpaw withdrawal responses to mechanical stimulation with von Frey monofilaments were assessed before morphine treatment $(\boldsymbol{A})$ and $30 \mathrm{~min}$ after the administration of each dose of morphine $(\boldsymbol{B}-\boldsymbol{E})$. ${ }^{*} p<0.05$, WT versus $B A M B I-K 0$ (repeated-measures ANOVA followed by Bonferroni's post hoc test). ${ }^{* *} p<0.01$, WT versus BAMBI-KO (repeated-measures ANOVA followed by Bonferroni's post hoc test).

effects. Thus, opioid resistance has been found in a variety of disease states, including neuropathic pain syndromes (Portenoy et al., 1990). Accordingly, our results show that wild-type mice subjected to SNI responded poorly to morphine; thus, mechanical allodynia was alleviated only after administering a total of 20 $\mathrm{mg} / \mathrm{kg}$ of morphine in a cumulative regimen of $1,3,6$, and $10 \mathrm{mg} / \mathrm{kg}$. These functional findings are in agreement with the neurochemical results, which show that $\mu$-opioid receptors from wild-type neuropathic mice had a reduced capability to inhibit forskolin-induced cAMP accumulation in spinal cord homogenates. However, $B A M B I-\mathrm{KO}$ mice, even in the fully developed neuropathic condition, were significantly more responsive to the antiallodynic effect of low morphine doses (3 and $6 \mathrm{mg} / \mathrm{kg}$ ). Whether $B A M B I$ deficiency improves the antiallodynic opioid effect in nociceptive tests based on different stimulus modalities (spontaneous and evoked) deserves further studies.

$B A M B I$ deficiency also resulted in an increased response to morphine under the chemical/inflammatory painful condition.
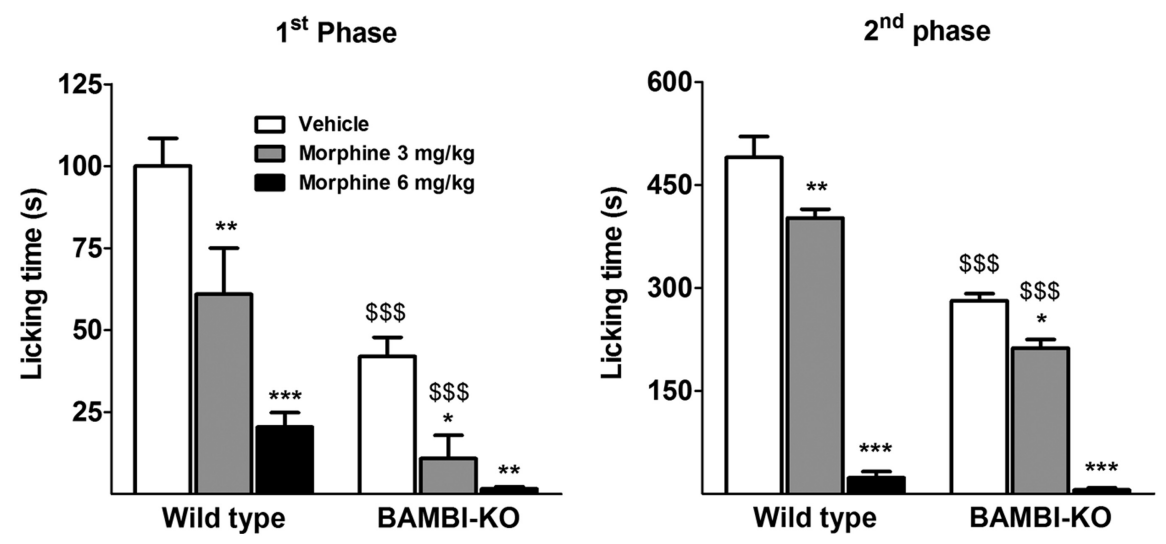

Figure 7. Antinociceptive effect of morphine in the formalin test of chemical/inflammatory pain. Mice received morphine or saline 30 min before the subcutaneous injection of formalin into the plantar surface of the left hindpaw. The results are expressed as the time spent licking the paw after formalin injection from 0 to $5 \mathrm{~min}$ (first phase) and from 20 to $60 \mathrm{~min}$ after injection (second phase). ${ }^{\$ \$ \$} p<0.001$, WT versus BAMBI-KO (two-way ANOVA followed by Bonferroni's post hoc test). ${ }^{*} p<0.05$, morphine versus vehicle (two-way ANOVA followed by Bonferroni's post hoc test). ${ }^{* *} p<0.01$, morphine versus vehicle (two-way ANOVA followed by Bonferroni's post hoc test). ${ }^{* * *} p<0.001$, morphine versus vehicle (two-way ANOVA followed by Bonferroni's post hoc test).
Therefore, the antinociceptive effect of $3 \mathrm{mg}$ morphine was significantly higher in $B A M B I-\mathrm{KO}$ than in WT mice in the formalin test. Is important to note that morphine, at the dose of $6 \mathrm{mg} / \mathrm{kg}$, almost abolished hindpaw licking behavior in the formalin model, which is in contrast to the "morphine resistance" exhibited by WT mice subjected to SNI. 
A

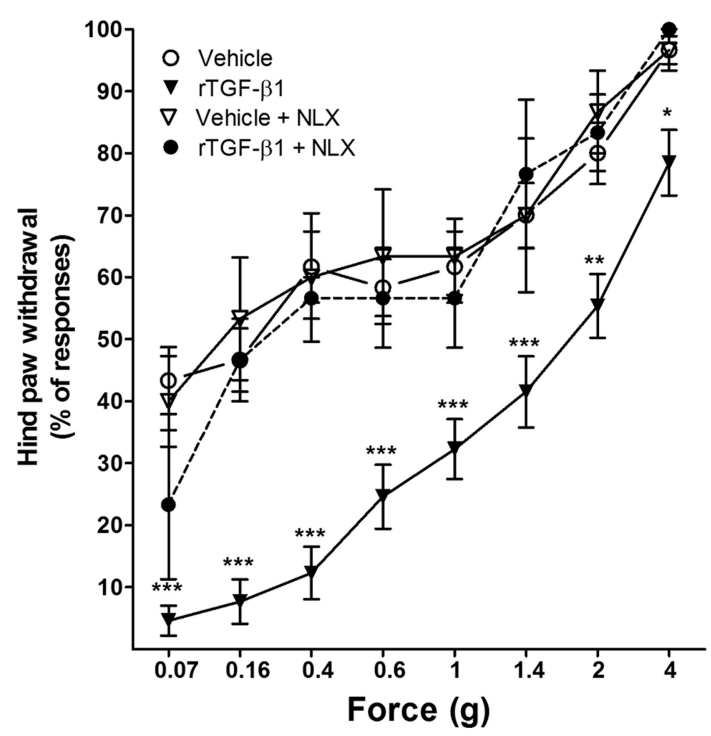

B

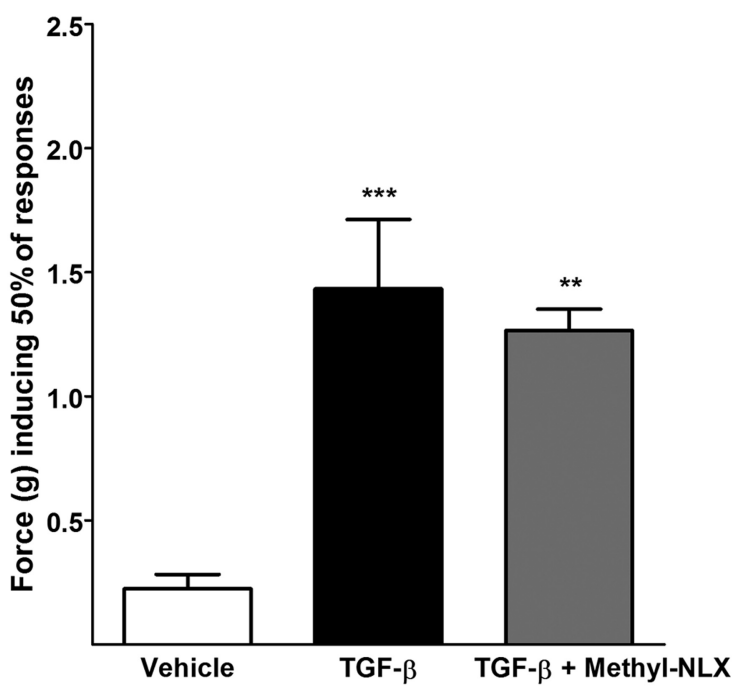

Figure 8. Behavioral manifestations of neuropathic pain (mechanical allodynia) evaluated with the von Frey monofilaments, on day 14 after SNI in wild-type mice. The data represent the percentage (mean \pm SEM) of hindpaw withdrawals elicited by mechanical stimuli of increasing strength, in wild-type mice treated with vehicle (open circles), recombinant TGF- $\beta 1$ (gray circles), or recombinant TGF- $\beta 1+$ naloxone (filled circles). Mice treated with recombinant TGF- $\beta 1$ developed significantly lower mechanical allodynia than vehicle-treated mice. The administration of an acute dose of naloxone $(1 \mathrm{mg} / \mathrm{kg}) 30$ min before performing the von Frey test on day 14 after nerve injury completely reverses the antiallodynic effect of TGF- $\beta 1$ ( $\boldsymbol{A}$ ), whereas methylnaloxone was ineffective $(\boldsymbol{B}) .{ }^{*} p<0.05$, vehicle versus rTGF- $\beta 1$ (repeated-measures ANOVA followed by Bonferroni's post hoc test). ${ }^{* *} p<0.01$, vehicle versus $r T G F-\beta 1$ (repeated-measures ANOVA followed by Bonferroni's post hoc test). ${ }^{* *} p<0.001$, vehicle versus rTGF- $\beta 1$ (repeated-measures ANOVA followed by Bonferroni's post hoc test).
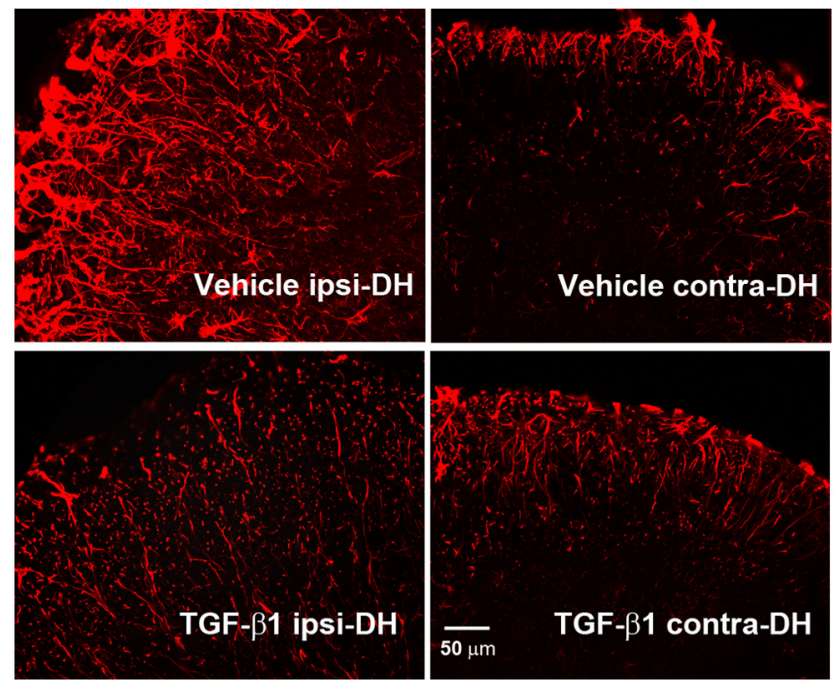

Figure 9. Effect of TGF- $\beta 1$ on spinal cord astrocytic reaction. SNI induced an astrocytic activation at the ipsilateral dorsal horn (DH), as evidenced by an increase in GFAP immunoreactivity. Subcutaneous infusion of TGF- $\beta 1$ for $14 \mathrm{~d}$ reduced GFAP immunoreactivity.

The mechanism accounting for such enhanced antinociceptive and antihyperalgesic responses to morphine could be related to the increased production of endogenous opioids exhibited by $B A M B I-K O$ mice (Tramullas et al., 2010). In this regard, it has been previously reported that endogenous opioid peptides with preferential affinity for $\delta$-receptors, such as enkephalins, present functional synergistic or additive interactions with exogenously administered $\mu$-opioid analgesics, such as morphine (Lee et al., 1980; Porreca et al., 1990; Rossi et al., 1993; Hurley and Hammond, 2001; Nieto et al., 2001; Hao et al., 2003). At the molecular level, it is now well admitted that enkephalin peptides promote the intracellular trafficking of $\mu-\delta$ receptor heteromers and sub- sequent recycling to the plasma membrane where the receptors can be activated again by agonists, reinitiating cellular signaling processes (Whistler et al., 1999; Song and Marvizón, 2003; Kabli et al., 2010). Finally, we may also hypothesize that the TGF- $\beta$ signaling gain, characteristic of $B A M B I-\mathrm{KO}$ mice may cause regulatory T-cell expansion and the release of IL-10, an antiinflammatory cytokine that has been reported to potentiate morphine analgesia (Johnston et al., 2004). Interestingly, the anti-inflammatory cytokines IL-10 and TGF- $\beta$ both have analgesic effects in animal models of neuropathic pain (Milligan et al., 2006; Echeverry et al., 2009; present results).

Spinal infusion of exogenous recombinant TGF- $\beta 1$ suppresses neuropathic pain development and reverses established pain in rats subjected to peripheral nerve injury (Echeverry et al., 2009). At the cellular level, TGF- $\beta$ prevents neuronal damage after peripheral nerve injury, inhibits microglial and astrocytic activation, and decreases the release of proinflammatory cytokines, such as IL-1 $\beta$ and IL-6, within the spinal cord (Echeverry et al., 2009). In harmony with the proven capability of this family of cytokines to cross the blood-brain barrier under neuroinflammatory conditions (Kastin et al., 2003; McLennan et al., 2005), here we show that subcutaneous infusion of TGF- $\beta 1$ was also efficacious in preventing neuropathic pain expression in mice subjected to SNI. Moreover, the protective effect of subcutaneous TGF- $\beta 1$ against astrocyte activation within the spinal cord was similar to that reported with intrathecal administration (Echeverry et al., 2009). Interestingly, in our study, the antiallodynic effect of TGF- $\beta 1$ was fully antagonized by a single injection of naloxone, whereas the opioid antagonist methylnaloxone, which does not cross the blood-brain barrier, was ineffective. These results suggest that the analgesic effect of subcutaneously administered TGF- $\beta 1$ is dependent on the activity of central "naloxonesensitive" endogenous pain modulatory circuits. Overall, our results and those of Echeverry et al. (2009) indicate that TGF- $\beta$ treatment can prevent the maladaptive plasticity induced within 
the CNS by peripheral nerve injury, which is responsible for the dysfunction of opioid inhibitory circuits and results in reduced inhibition/enhanced facilitation of pain transmission. In addition, despite the presence of a mechanism capable of inducing pain (peripheral nerve injury), our observations indicate that engagement of opioidergic signaling in pain-modulating areas by TGF- $\beta$ is a critical factor that can prevent the neuropathic pain behavioral manifestation.

In conclusion, our results show that presynaptic and postsynaptic modulation of the endogenous opioid system by TGF- $\beta$ signaling can prevent allodynia development and improve the analgesic effectiveness of exogenous and endogenous opioid agonists under conditions of pathological pain. The potential value of TGF- $\beta$ signaling as a therapeutic target for treating opioidresistant painful conditions, particularly neuropathic pain, deserves further attention.

\section{References}

Austin PJ, Moalem-Taylor G (2010) The neuro-immune balance in neuropathic pain: involvement of inflammatory immune cells, immune-like glial cells and cytokines. J Neuroimmunol 229:26-50. CrossRef Medline

Basbaum AI, Bautista DM, Scherrer G, Julius D (2009) Cellular and molecular mechanisms of pain. Cell 139:267-284. CrossRef Medline

Bester H, Beggs S, Woolf CJ (2000) Changes in tactile stimuli-induced behavior and c-Fos expression in the superficial dorsal horn and in parabrachial nuclei after sciatic nerve crush. J Comp Neurol 428:45-61. CrossRef Medline

Bouhassira D, Lantéri-Minet M, Attal N, Laurent B, Touboul C (2008) Prevalence of chronic pain with neuropathic characteristics in the general population. Pain 136:380-387. CrossRef Medline

Breivik H, Collett B, Ventafridda V, Cohen R, Gallacher D (2006) Survey of chronic pain in Europe: prevalence, impact on daily life, and treatment. Eur J Pain 10:287-333. CrossRef Medline

Calvo M, Dawes JM, Bennett DL (2012) The role of the immune system in the generation of neuropathic pain. Lancet Neurol 11:629-642. CrossRef Medline

Cervero F (2009) Pain: friend or foe? A neurobiologic perspective: the 2008 Bonica Award Lecture. Anesth Pain Med 34:569-574. CrossRef Medline

Coderre TJ, Vaccarino AL, Melzack R (1990) Central nervous system plasticity in the tonic pain response to subcutaneous formalin injection. Brain Res 535:155-158. CrossRef Medline

Daugé V, Mauborgne A, Cesselin F, Fournié-Zaluski MC, Roques BP (1996) The dual peptidase inhibitor RB101 induces a long-lasting increase in the 27extracellular level of Met-enkephalin-like material in the nucleus accumbens of freely moving rats. J Neurochem 67:1301-1308. CrossRef Medline

Echeverry S, Shi XQ, Haw A, Liu H, Zhang ZW, Zhang J (2009) Transforming growth factor-betal impairs neuropathic pain through pleiotropic effects. Mol Pain 5:16. CrossRef Medline

Echeverry S, Wu Y, Zhang J (2013) Selectively reducing cytokine/chemokine expressing macrophages in injured nerves impairs the development of neuropathic pain. Exp Neurol 240:205-218. CrossRef Medline

Fink DJ, Wechuck J, Mata M, Glorioso JC, Goss J, Krisky D, Wolfe D (2011) Gene therapy for pain: results of a phase I clinical trial. Ann Neurol 70:207-212. CrossRef Medline

Finnerup NB, Otto M, McQuay HJ Jensen TS, Sindrup SH (2005) Algorithm for neuropathic pain treatment: an evidence based proposal. Pain 118:289-305. CrossRef Medline

Fournié-Zaluski MC, Coric P, Turcaud S, Lucas E, Noble F, Maldonado R, Roques BP (1992) "Mixed inhibitor-prodrug" as a new approach toward systemically active inhibitors of enkephalin-degrading enzymes. J Med Chem 35:2473-2481. CrossRef Medline

George SR, Fan T, Xie Z, Tse R, Tam V, Varghese G, O’Dowd BF (2000) Oligomerization of mu- and delta-opioid receptors: generation of novel functional properties. J Biol Chem 275:26128-261335. CrossRef Medline

Goss JR, Mata M, Goins WF, Wu HH, Glorioso JC, Fink DJ (2001) Antinociceptive effect of a genomic herpes simplex virus-based vector expressing human proenkephalin in rat dorsal root ganglion. Gene Ther 8:551-556. CrossRef Medline

Hao S, Mata M, Goins W, Glorioso JC, Fink DJ (2003) Transgene-mediated enkephalin release enhances the effect of morphine and evades tolerance to produce a sustained antiallodynic effect in neuropathic pain. Pain 102: 135-142. CrossRef Medline

Hurley RW, Hammond DL (2001) Contribution of endogenous enkephalins to the enhanced analgesic effects of supraspinal mu opioid receptor agonists after inflammatory injury. J Neurosci 21:2536-2545. Medline

Johnston IN, Milligan ED, Wieseler-Frank J, Frank MG, Zapata V, Campisi J, Langer S, Martin D, Green P, Fleshner M, Leinwand L, Maier SF, Watkins LR (2004) A role for proinflammatory cytokines and fractalkine in analgesia, tolerance, and subsequent pain facilitation induced by chronic intrathecal morphine J Neurosci 24:7353-7365. CrossRef

Kabli N, Martin N, Fan T, Nguyen T, Hasbi A, Balboni G, O'Dowd BF, George SR (2010) Agonists at the $\delta$-opioid receptor modify the binding of $\mu$-receptor agonists to the $\mu$ - $\delta$ receptor hetero-oligomer. Br J Pharmacol 161:1122-1136. CrossRef Medline

Kastin AJ, Akerstrom V, Pan W (2003) Circulating TGF-betal does not cross the intact blood-brain barrier. J Mol Neurosci 21:43-48. CrossRef Medline

Kim KS, Lee KW, Lee KW, Im JY, Yoo JY, Kim SW, Lee JK, Nestler EJ, Han PL (2006) Adenylyl cyclase type 5 (AC5) is an essential mediator of morphine action. Proc Natl Acad Sci U S A 103:3908-3913. CrossRef Medline

König M, Zimmer AM, Steiner H, Holmes PV, Crawley JN, Brownstein MJ, Zimmer A (1996) Pain responses, anxiety and aggression in mice deficient in pre-proenkephalin. Nature 383:535-538. CrossRef Medline

Lantero A, Tramullas M, Díaz A, Hurlé MA (2012) Transforming growth factor- $\beta$ in normal nociceptive processing and pathological pain models Mol Neurobiol 45:76-86. CrossRef

Law PY, Wong YH, Loh HH (2000) Molecular mechanisms and regulation of opioid receptor signaling. Annu Rev Pharmacol Toxicol 40:389-430. CrossRef Medline

Lee NM, Leybin L, Chang JK, Loh HH (1980) Opiate and peptide interaction: effect of enkephalins on morphine analgesia. Eur J Pharmacol 68: 181-185. CrossRef Medline

Le Guen S, Mas Nieto M, Canestrelli C, Chen H, Fournié-Zaluski MC, Cupo A, Maldonado R, Roques BP, Noble F (2003) Pain management by a new series of dual inhibitors of enkephalin degrading enzymes: long lasting antinociceptive properties and potentiation by CCK2 antagonist or methadone. Pain 104:139-148. CrossRef Medline

Massagué J (2012) TGF $\beta$ signalling in context. Nat Rev Mol Cell Biol 13: 616-630. CrossRef Medline

McLennan IS, Weible MW 2nd, Hendry IA, Koishi K (2005) Transport of transforming growth factor-beta 2 across the blood-brain barrier. Neuropharmacology 48:274-282. CrossRef Medline

McNamara CR, Mandel-Brehm J, Bautista DM, Siemens J, Deranian KL, Zhao M, Hayward NJ, Chong JA, Julius D, Moran MM, Fanger CM (2007) TRPA1 mediates formalin-induced pain. Proc Natl Acad Sci U S A 104:13525-13530. CrossRef Medline

Milligan ED, Watkins LR (2009) Pathological and protective roles of glia in chronic pain. Nat Rev Neurosci 10:23-36. CrossRef Medline

Milligan ED, Soderquist RG, Malone SM, Mahoney JH, Hughes TS, Langer SJ, Sloane EM, Maier SF, Leinwand LA, Watkins LR, Mahoney MJ (2006) Intrathecal polymer-based interleukin-10 gene delivery for neuropathic pain. Neuron Glia Biol 2:293-308. CrossRef Medline

Mostany R, Díaz A, Valdizán EM, Rodríguez-Muñoz M, Garzón J, Hurlé MA (2008) Supersensitivity to $\mu$-opioid receptor-mediated inhibition of the adenylyl cyclase pathway involves pertussis toxin-resistant $\mathrm{G} \alpha$ protein subunits. Neuropharmacology 54:989-997. CrossRef Medline

Nieto MM, Wilson J, Walker J, Benavides J, Fournie-Zaluski MC, Roques BP, Noble F (2001) Facilitation of enkephalins catabolism inhibitor-induced antinociception by drugs classically used in pain management. Neuropharmacology 41:496-506. CrossRef Medline

Noble F, Soleilhac JM, Soroca-Lucas E, Turcaud S, Fournie-Zaluski MC, Roques BP (1992) Inhibition of the enkephalin-metabolizing enzymes by the first systemically active mixed inhibitor prodrug RB 101 induces potent analgesic responses in mice and rats. J Pharmacol Exp Ther 261: 181-190. Medline

Noble F, Benturquia N, Bilkei-Gorzo A, Zimmer A, Roques BP (2008) Use of preproenkephalin knockout mice and selective inhibitors of enkephalinases to investigate the role of enkephalins in various behaviours. Psychopharmacology 196:327-335. CrossRef Medline

Onichtchouk D, Chen YG, Dosch R, Gawantka V, Delius H, Massagué J, 
Niehrs C (1999) Silencing of TGF- $\beta$ signalling by the pseudoreceptor BAMBI. Nature 401:480-485. CrossRef Medline

Ossipov MH, Dussor GO, Porreca F (2010) Central modulation of pain. J Clin Invest 120:3779-3787. CrossRef Medline

Pierre S, Eschenhagen T, Geisslinger G, Scholich K (2009) Capturing adenylyl cyclases as potential drug targets. Nat Rev Drug Discov 8:321-335. CrossRef Medline

Porreca F, Jiang Q, Tallarida RJ (1990) Modulation of morphine antinociception by peripheral [Leu5] enkephalin: a synergistic interaction. Eur J Pharmacol 179:463-468. CrossRef Medline

Portenoy RK, Foley KM, Inturrisi CE (1990) The nature of opioid responsiveness and its implications for neuropathic pain: new hypotheses derived from studies of opioid infusions. Pain 43:273-286. CrossRef Medline

Ren K, Dubner R (2010) Interactions between the immune and nervous systems in pain. Nat Med 16:1267-1276. CrossRef Medline

Roques BP, Fournié-Zaluski MC, Wurm M (2012) Inhibiting the breakdown of endogenous opioids and cannabinoids to alleviate pain. Nat Rev Drug Discov 11:292-310. CrossRef Medline

Rossi GC, Pasternak GW, Bodnar RJ (1993) Synergistic brainstem interactions for morphine analgesia. Brain Res 624:171-180. CrossRef Medline

Song B, Marvizón JC (2003) Peptidases prevent $\mu$-opioid receptor internalization in dorsal horn neurons by endogenously released opioids. J Neurosci 23:1847-1858. Medline

Tjølsen A, Berge OG, Hunskaar S, Rosland JH, Hole K (1992) The formalin test: an evaluation of the method. Pain 51:5-17. CrossRef Medline
Tramullas M, Lantero A, Díaz A, Morchón N, Merino D, Villar A, Buscher D, Merino R, Hurlé JM, Izpisúa-Belmonte JC, Hurlé MA (2010) BMP and Activin membrane-bound inhibitor (BAMBI) reveals the involvement of the TGF- $\beta$ family in pain modulation. J Neurosci 30:1502-1511. CrossRef Medline

Valdizán EM, Díaz A, Pilar-Cuéllar F, Lantero A, Mostany R, Villar AV, Laorden ML, Hurlé MA (2012) Chronic treatment with the opioid antagonist naltrexone favours the coupling of spinal cord $\mu$-opioid receptors to G $\alpha z$ protein subunits. Neuropharmacology 62:757-764. CrossRef Medline

von Hehn CA, Baron R, Woolf CJ (2012) Deconstructing the neuropathic pain phenotype to reveal neural mechanisms. Neuron 73:638-652. CrossRef Medline

Wharton K, Derynck R (2009) TGF $\beta$ family signaling: novel insights in development and disease. Development 136:3691-3697. CrossRef Medline

Whistler JL, Chuang HH, Chu P, Jan LY, von Zastrow M (1999) Functional dissociation of $\mu$ opioid receptor signaling and endocytosis: implications for the biology of opiate tolerance and addiction. Neuron 23:737-746. CrossRef Medline

Woolf CJ, Ma Q (2007) Nociceptors-noxious stimulus detectors. Neuron 55:353-364. CrossRef Medline

Yaksh TL, Gross KE, Li CH (1982) Studies on the intrathecal effect of $\beta$-endorphin in primates. Brain Res 241:261-269. CrossRef Medline

Zimmermann M (1983) Ethical guidelines for investigations of experimental pain in conscious animals. Pain 16:109-110. CrossRef Medline 